\title{
Geochemical evidence for widespread euxinia in the Later Cambrian ocean
}

\section{Citation}

Gill, Benjamin C., Timothy W. Lyons, Seth A. Young, Lee R. Kump, Andrew H. Knoll, and Matthew R. Saltzman. 2011. "Geochemical Evidence for Widespread Euxinia in the Later Cambrian

Ocean." Nature 469, no. 7328: 80-83.

\section{Published Version}

doi:10.1038/nature09700

\section{Permanent link}

http://nrs.harvard.edu/urn-3:HUL.InstRepos:13041344

\section{Terms of Use}

This article was downloaded from Harvard University's DASH repository, and is made available under the terms and conditions applicable to Open Access Policy Articles, as set forth at http:// nrs.harvard.edu/urn-3:HUL.InstRepos:dash.current.terms-of-use\#OAP

\section{Share Your Story}

The Harvard community has made this article openly available.

Please share how this access benefits you. Submit a story.

\section{Accessibility}




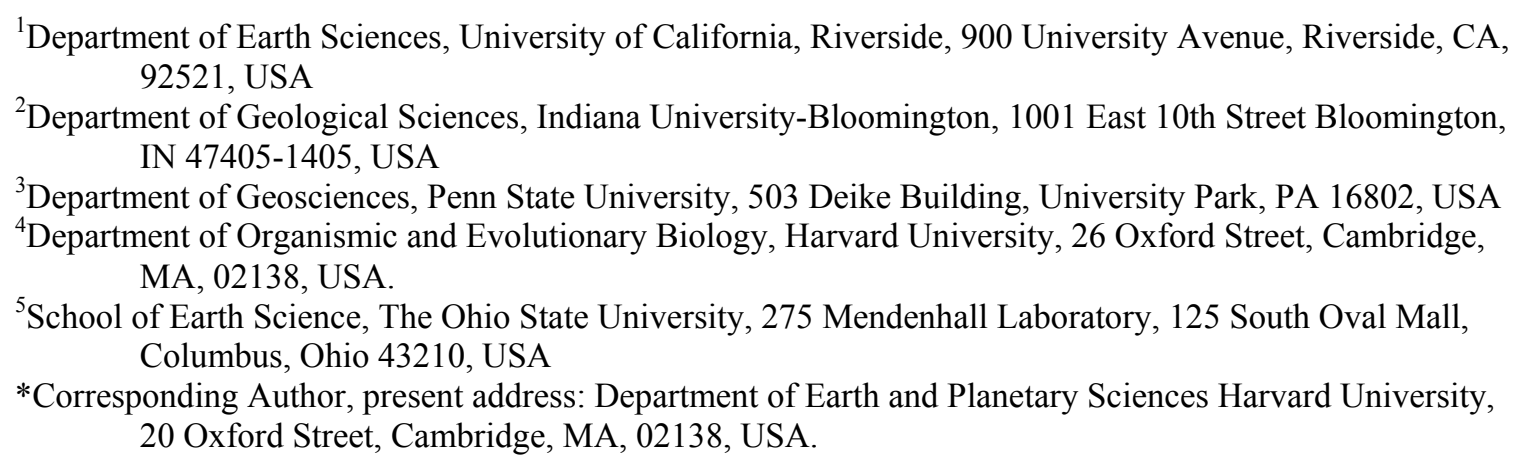
92521, USA

${ }^{2}$ Department of Geological Sciences, Indiana University-Bloomington, 1001 East 10th Street Bloomington, IN 47405-1405, USA

${ }^{3}$ Department of Geosciences, Penn State University, 503 Deike Building, University Park, PA 16802, USA

${ }^{4}$ Department of Organismic and Evolutionary Biology, Harvard University, 26 Oxford Street, Cambridge, MA, 02138, USA.

${ }^{5}$ School of Earth Science, The Ohio State University, 275 Mendenhall Laboratory, 125 South Oval Mall, Columbus, Ohio 43210, USA

*Corresponding Author, present address: Department of Earth and Planetary Sciences Harvard University, 20 Oxford Street, Cambridge, MA, 02138, USA.

Global-scale anoxia in the deep ocean is frequently invoked as a primary

19 driver of mass extinction, as well as a long-term inhibitor of evolutionary radiation

20 on the early Earth. In recent biogeochemical studies, it has been hypothesized that

21 oxygen deficiency was widespread in subsurface water masses of later Cambrian

22 oceans $^{1,2}$, possibly influencing evolutionary events during this time ${ }^{1,2,3}$. Physical

23 evidence of widespread anoxia in Cambrian oceans has remained elusive, and thus

24 its potential relationship to the paleontological record remains largely unexplored.

25 Here, we present sulphur isotope records from six globally distributed stratigraphic

26 sections of later Cambrian marine rocks (ca. 499 million years old) that show a

27 positive excursion in phase with the well-known Steptoean Positive Carbon Isotope

28 Excursion (SPICE). Numerical box modeling of the paired carbon-sulphur isotope 
data indicates that these isotope shifts reflect transient increases in the burial of

30 organic carbon and pyrite sulphur in sediments deposited under ocean-scale anoxic

31 and sulphidic (euxinic) conditions. Independently, molybdenum abundances in a

32 coeval black shale point convincingly to ocean-scale anoxia. These results identify

33 the SPICE interval as the best characterized ocean anoxic event in the pre-Mesozoic

34 ocean and an extreme example of oxygen deficiency in the later Cambrian deep

35 ocean. Thus, a redox structure similar to those in Proterozoic oceans ${ }^{4,5,6}$ may have

36 persisted or returned in the oceans of the early Phanerozoic Eon. Indeed, the

37 environmental challenges presented by widespread anoxia may have been a

38 prevalent if not dominant influence on animal evolution in Cambrian oceans.

40 Carbonate rocks of Cambrian age preserve large, rapid (of a few million years

41 duration or less) and globally correlated excursions in the marine carbon isotope record

$42\left(\delta^{13} \mathrm{C}_{\text {carb }} \text { ), which indicate perturbations in the global carbon cycle (Figure } \mathrm{S} 1\right)^{7,8,9,10}$. The

43 mechanisms that drove these events, however, are poorly known. What makes these

44 excursions particularly interesting to geobiologists is the observation that many coincide

45 with biological events recorded by fossils, suggesting causal links between biological and

46 environmental history ${ }^{3,10}$. The focus of our work is on the last large excursion of the

47 period, the Steptoean Positive Carbon Isotope Excursion, or SPICE.

48 The SPICE is recorded as a $+4-6 \%$ shift in $\delta^{13} \mathrm{C}_{\text {carb }}$ that occurs globally in later

49 Cambrian successions (at the beginning of the Furongian International Series and Paibian

50 International Stage, $499 \mathrm{Ma}$ ); it is thought to have lasted on the order of 2-4 million 
51 years ${ }^{10,11}$. A well-documented extinction of trilobites coincides with the onset of the

52 SPICE on the paleocontinent of Laurentia ${ }^{10,12}$, and the isotopic excursion has also been

53 correlated to intervals of biological turnover on other paleocontinents ${ }^{13}$. The SPICE is

54 also coincident with global changes in sea level; its onset coincides with a transgressive

55 event, and its peak is concurrent with a lowstand recorded as the Sauk-II/III hiatus ${ }^{10,11}$.

56 We report sulphur isotope data from six globally distributed stratigraphic sections

57 across the SPICE, and each reveal parallel, positive carbon and sulphur isotope

58 excursions (Figures 1, 2 and 3). These sections represent diverse sedimentary

59 environments; thus, similarities among the trends despite differences in depositional

60 conditions speak to the global and primary nature of the geochemical signals (see

61 Supplementary Materials for details of individual stratigraphic sections and data

62 supporting the preservation of the geochemical signals).

63 The SPICE sulphur isotope excursion is one of the largest identified in the

64 geologic record and is the first to be correlated globally at this scale of resolution. This

65 excursion occurs in both carbonate-associated sulphate (CAS) and pyrite, which further

66 supports a primary marine signal, and its magnitude indicates a major perturbation in the

67 global sulphur cycle. There are, however, significant differences in the details of the

68 sulphate sulphur isotope trends among basins. In particular, the pre-event $\delta^{34} \mathrm{~S}_{\mathrm{CAS}}$

69 baseline differs among the various locations (Figure 2). While some records show

70 relatively steady sulphur isotope values before the excursion (i.e., western and eastern

71 Laurentia), the Gondwanan data show a positive trend up section before the excursion

72 (Figure 2). 
73 Despite overarching similarities, the absolute values and amplitudes of the

74 excursion also differ among the studied basins. The Gondwanan record is the most

75 extreme, with $\delta^{34} \mathrm{~S}_{\mathrm{CAS}}$ values reaching almost $+70 \%$ and an amplitude of $+35 \%$ (Figure

76 2). On the other end of the spectrum, the record in eastern Laurentia shows a peak value

77 of $+38 \%$ and amplitude of only $+12 \%$ (Figure 2 ). These isotopic differences support the

78 idea that the sulphur reservoir in the later Cambrian ocean was spatially heterogeneous

79 and that sulphate concentrations were therefore low ${ }^{14,15}$. We also observe that the sulfate

80 isotope excursion peaks stratigraphically slightly before the carbon isotope maximum

81 (see Supplementary Figure S2), which suggests that the sulphate reservoir was relatively

82 more sensitive to change than the marine pool of dissolved inorganic carbon (DIC). This

83 state of sulphate in later Cambrian seawater differs greatly from the modern reservoir,

84 which is relatively homogenous globally with a concentration of $28 \mathrm{mmol} / \mathrm{kg}(\mathrm{mM})$ and a

85 sulphur isotope composition of $+21 \%$. This contrast with the modern ocean indicates

86 that the residence time of sulphate in the Cambrian ocean was much shorter.

87 The parallel behavior between the carbon and sulphur isotope excursions

88 (Figures 2 and 3) suggests that the SPICE records a transient increase in the amount of

89 carbon and sulphur buried as organic matter and pyrite $\left(\mathrm{FeS}_{2}\right)$ in marine sediments. Such

90 parallel burial occurs in anoxic marine sediments and beneath euxinic water columns ${ }^{16}$ -

91 that is, beneath water columns that are both anoxic and contain free hydrogen sulphide.

92 Organic matter fuels microbial sulphate reduction (MSR), and pyrite is formed when $\mathrm{H}_{2} \mathrm{~S}$

93 produced from MSR reacts with iron minerals and is buried along with the residual

94 organic matter. Ultimately, the burial of both species results in the removal of carbon 
95 and sulphur from the ocean. This coupling can result in positive isotope shifts for both

96 species in seawater: the carbon and sulphur leaving the ocean through burial are enriched

97 in ${ }^{12} \mathrm{C}$ and ${ }^{32} \mathrm{~S}$ via isotope fractionations accompanying photosynthetic and MSR

98 pathways, respectively, leaving the seawater correspondingly enriched in ${ }^{13} \mathrm{C}$ and ${ }^{34} \mathrm{~S}$.

99 We tested this hypothesis by modeling the ocean inventories of carbon and

100 sulphur during the SPICE. Specifically, we constructed a simple box model that

101 simulates the cycling of each element in the ocean (see Supplementary Material for

102 details). The model shows that the isotope excursions can be replicated by transiently

103 increasing the amount of organic carbon buried by factors of 1.5 to 2.5 and pyrite sulphur

104 by factors of 2.5 to 4.5 for a duration of 0.5 to 1.5 million years (Figure 4 : see

105 Supplementary Material for additional model details).

106 Importantly, our model puts quantitative constraints on the size of the marine

107 sulphate reservoir during the later Cambrian. An assumption of pre-SPICE sulphate

108 concentrations greater than $2.5 \mathrm{mM}$ demands more than 8 million years for recovery of

$109 \delta^{34} \mathrm{~S}_{\text {sulphate }}$ (i.e., return to the pre-event baseline) following the SPICE (Figure S13), which

110 is unreasonable in light of the available constraints on the duration of the SPICE ${ }^{11}$. Our

111 simulations suggest, therefore, that the concentration of seawater sulphate was very low

112 - at or below the low end of the 2-12 $\mathrm{mM}$ range suggested by previous work ${ }^{14,15}$.

113 Another important result from the model is that the predicted ratio of carbon-to-

114 sulphur $(\mathrm{C} / \mathrm{S})$ linked to this transient burial was very low: 1 to 4 moles $\mathrm{C} / \mathrm{mole} \mathrm{S}$ or $0.4-$

$1151.5 \mathrm{~g} \mathrm{C} / \mathrm{g} \mathrm{S}$ (Figure 4). In younger sediments, similar $\mathrm{C} / \mathrm{S}$ ratios are only observed in

116 sediments deposited under euxinic conditions ${ }^{16}$. The scale of this Cambrian euxinia is 
117 suggested by comparison to the Black Sea, the largest modern euxinic basin. Our

118 estimates for the transient burial flux of sulfur that caused the isotope excursion are equal

119 to 50-75 times that of the euxinic portion Black Sea ${ }^{17}$, thus providing the first quantitative

120 evidence for global-scale euxinia in the Paleozoic ocean.

121 Our argument for increased euxinia becomes stronger when we consider that $\Delta \mathrm{S}$

122 may have decreased over the event (Figure 2). $\Delta \mathrm{S}$ is the isotopic offset between

123 coexisting CAS and pyrite $\left(\Delta \delta^{34} \mathrm{~S}_{\mathrm{CAS}-\text { pyrite }}\right)$ that results from MSR and related microbial

124 pathways that lead to pyrite formation. For the two sections that have sufficient pyrite for

125 isotopic analysis (eastern Laurentia and Gondwana), there is a strikingly systematic

126 negative shift in $\Delta \mathrm{S}$ parallel to the positive excursions in $\delta^{34} \mathrm{~S}_{\mathrm{CAS}}$ and $\delta^{13} \mathrm{C}_{\text {carb }}$ (Figure 2).

127 Importantly, a smaller $\Delta \mathrm{S}$, when applied to our model, requires greater pyrite burial to

128 explain the positive sulphur excursion. The further increase in pyrite burial results in an

129 even lower mean $\mathrm{C} / \mathrm{S}$ ratio, strengthening the case for burial under euxinic conditions

130 (see Supplementary Figure S14 for sensitivity tests of $\Delta \mathrm{S}$ ). Our Cambrian sulphur

131 isotope data must record a decrease in seawater sulphate concentration associated with

132 voluminous euxinic pyrite burial during the SPICE under generally low levels of

133 sulphate.

134 Additional evidence for the expansion of euxinic conditions comes from the

135 coeval Alum Shale in Sweden, where a systematic decrease in molybdenum enrichment

136 coincides with the SPICE (Figure 3). Molybdenum is a transition metal, typically

137 enriched in organic-rich sediments deposited under euxinic conditions ${ }^{18,19}$. The

138 variability in molybdenum concentrations occurs despite iron proxy data that indicate 
139 persistent euxinia over the interval of interest (Figure 3); the Alum basin appears to have

140 been locally euxinic before, during and after the SPICE. The suggestion then is that

141 another process drove the scale of enrichment. In short, the decline going into the SPICE

142 and increase coming out argue for a decrease in the global molybdenum inventory of

143 seawater as the euxinic conditions expanded and then contracted on a global scale $e^{6,19,20}$

144 - a scenario consistent with the predictions of the modeled $\mathrm{C}$ and $\mathrm{S}$ data. We envision

145 conditions during the SPICE to have been analogous to those during oceanic anoxic

146 events or OAEs of the Mesozoic, where the spread of euxinic conditions led to extensive

147 deposition of organic-rich, pyritic sediments in the deep ocean yielding concomitant

148 isotopic shifts in dissolved inorganic carbon ${ }^{21}$ and seawater sulfate ${ }^{22}$.

149 The geochemical and stratigraphic framework of the SPICE provides new insight

150 into the pronounced biological turnover associated with this event. Taken together with

151 evidence for sea-level rise, the geochemical data suggest that shoaling of toxic anoxic

152 deep waters onto the shelf led to the extinction of shelf fauna, a situation similar to that

153 envisioned for end-Permian extinctions ${ }^{23}$. Such a scenario was proposed previously to

154 explain recurrent later Cambrian trilobite extinctions ${ }^{12}$ but in acknowledged absence of

155 independent constraints for such conditions.

156 Additional oscillations observed in the later Cambrian marine $\delta^{13} \mathrm{C}$ record could

157 reflect environmental perturbations similar to the SPICE. We suggest that anoxic water

158 masses occurred widely in the subsurface of the later Cambrian ocean (i.e., below the

159 wind-mixed surface layer), a view that finds qualitative support in the stratigraphic

160 distribution of organic-rich, pyritic black shales, which peak in abundance in later 
161 Cambrian successions $^{24}$. If correct, the high rates of biological turnover ${ }^{25}$ and repeated

162 trilobite extinctions ${ }^{12,26}$ documented for later Cambrian fossils find at least partial

163 explanation in episodic expansion of oxygen-depleted waters. In larger terms, broad

164 patterns of Cambrian animal evolution may reflect persistent oxygen deficiency in

165 subsurface waters of Cambrian oceans, shedding new light on early evolution of the

166 Phanerozoic biosphere in the wake of late Proterozoic oxygenation.

167

168

169

170

171

172

173

174

175

176

177

178

179

180

\section{References}

1 Hough, M. L. et al. A major sulphur isotope event at c. $510 \mathrm{Ma}$ : a possible anoxia-extinction-volcanism connection during the Early-Middle Cambrian

transition? Terra Nova 18, 257-263 (2006).

2 Hurtgen, M. T., Pruss, S. B. \& Knoll, A. H. Evaluating the relationship between the carbon and sulfur cycles in the later Cambrian ocean: An example from the Port au Port Group, western Newfoundland, Canada. Earth Planet. Sci. Lett. 281, 288-297 (2009).

3 Zhuravlev, A. \& Wood, R. Anoxia as the cause of the mid-Early Cambrian (Botomian) extinction event. Geology 24, 311-314 (1996).

4 Canfield, D. E. A new model for Proterozoic ocean chemistry. Nature 396, 4505453 (1998).

$5 \quad$ Poulton, S. W., Fralick, P. W. \& Canfield, D. E. The transition to a sulphidic ocean $\sim 1.84$ billion years ago. Nature 431, 173-177 (2004).

6 Scott, C. et al. Tracing the stepwise oxygenation of the Proterozoic ocean. Nature 452, 456-459 (2008).

Brasier, M. D., Corfield, R. M., Derry, L. A., Rozanov, A. Y. \& Zhuravlev, A. Y. $186 \quad$ Multiple $\delta^{13} \mathrm{C}$ excursions spanning the Cambrian explosion to the Botomian crisis 187 in Siberia Geology 22, 455-458 (1994).

$188 \quad$ Saltzman, M. R., Runnegar, B. \& Lohmann, K. C. Carbon isotope stratigraphy of 189 Upper Cambrian (Steptoean Stage) sequences of the eastern Great Basin: Record $190 \quad$ of a global oceanographic event Geol. Soc. Am. Bull. 110, 285-297 (1998).

1919 Montanez, I. P., Osleger, D. A., Banner, J. L., Mack, L. E. \& Musgrove, M. Evolution of the $\mathrm{Sr}$ and $\mathrm{C}$ isotope composition of Cambrian Oceans. GSA Today 10, 1-7 (2000). 
Saltzman, M. R. et al. The Late Cambrian SPICE $\left(\delta^{13} \mathrm{C}\right)$ Event and the Sauk IISAUK III Regression: New Evidence from Laurentian Basins in Utah, Iowa and Newfoundland. J. Sed. Res. 74, 366-377 (2004).

Palmer, A. The Biomere Problem: Evolution of an Idea. Journal of Paleontology 58, 599-611 (1984).

Peng, S. et al. Global Standard Stratotype-section and Point of the Furongian Series and Paibian Stage Cambrian. Lethaia 37, 365-379 (2004).

Brennan, S. T., Lowenstein, T. K. \& Horita, J. Seawater chemistry and the advent of biocalcification. Geology 32, 473-476 (2004).

5 Gill, B. C., Lyons, T. W. \& Saltzman, M. R. Parallel, high-resolution carbon and sulfur isotope records of the evolving Paleozoic marine sulfur reservoir.

Palaeogeogr. Palaeoclimatol. Palaeoecol. 256, 156-173 (2007).

Berner, R. Sedimentary pyrite formation: An update. Geochim. Cosmochim. Acta 48, 605-615 (1984).

Neretin, L. N., Volkov, I. I., Böttcher, M. E. \& Grinenko, V. A. A sulfur budget for the Black Sea anoxic zone. Deep-Sea Research Part I 48, 2569-2593 (2001). Emerson, S. \& Huested, S. Ocean anoxia and the concentrations of molybdenum and vanadium in seawater. Mar. Chem. 34, 177-196 (1991).

Algeo, T. J. \& Lyons, T. W. Mo-total organic carbon covariation in modern anoxic marine environments: Implications for analysis of paleoredox and paleohydrographic conditions. Paleoceangraphy 21, 23 (2006).

Algeo, T. J. Can marine anoxic events draw down the trace element inventory of seawater? Geology 32, 1057-1060 (2004).

Arthur, M. A., Dean, W. E. \& Pratt, L. M. Geochemical and climatic effects of increased marine organic carbon burial at the Cenomanian/Turonian boundary. Nature 335, 714-717 (1988).

Adams, D. D., Hurtgen, M. T. \& Sageman, B. B. Volcanic triggering of a biogeochemical cascade during Oceanic Anoxic Event 2. Nat. Geosci. 3, 1-4 (2010).

Wignall, P. B. \& Twitchett, R. J. Oceanic Anoxia and the End Permian Mass Extinction. Science 272, 1155-1158 (1996).

Berry, W. B. N. \& Wilde, P. Progressive ventilation of the oceans; an explanation for the distribution of the lower Paleozoic black shales. Am. J. Sci. 278, 257-275 (1978).

Bambach, R. K., Knoll, A. H. \& Wang, S. C. Origination, extinction, and mass depletions of marine diversity. Paleobiology 30, 522-542 (2004).

Palmer, A. R. Biomere: A New Kind of Biostratigraphic Unit. Journal of Paleontology 39, 149-153 (1965).

Scotese, C. R., Atlas of Earth History (Arlington, Texas, 2001).

Ahlberg, P. et al. Cambrian high-resolution biostratigraphy and carbon isotope chemostratigraphy in Scania, Sweden: first record of the SPICE and DICE excursions in Scandinavia. Lethaia, 13 (2008). 
Lyons, T. W. \& Severmann, S. A critical look at iron paleoredox proxies: New insights from modern euxinic marine basins. Geochimica Cosmochimica Acta 70, 5698-5722 (2006).

30 Raiswell, R., Buckley, F., Berner, R. A. \& Anderson, T. F. Degree of pyritization of iron as a paleoenvironmental indicator of bottom-water oxygenation. J. Sed. Res. 58, 812-819 (1988).

Author contributions BCG, TWL, MRS, SY collected samples used in this study. BCG did the chemical analyzes and collected mass spectrometer and ICP-MS data. BCG and LRK built the geochemical box model. BCG wrote the manuscript, with contributions from TWL, AHK and LRK. All the authors contributed to discussion and interpretations.

Acknowledgements NSF-EAR and NASA Astrobiology provided funding. Fieldwork and sample collection were aided by S. Bates, L. Bongers, H. Dayton, S. Mason, P. McGoldrick, J. Owens, C. Seeger, E. Starbuck. Sulphur isotope analyzes were aided by S. Bates and W. Gilhooly. Discussions with G. Love, N. Hughes, D. Johnston, P. Cohen and T. Dahl improved the manuscript.

\section{Figure captions}

260 SPICE has been identified (filled circles). Locations investigated in this study: Western

261 Laurentia (WL) - Shingle Pass and Lawson Cove, Great Basin USA; Eastern Laurentia

262 (EL) - TE-1 Texas County Core, Missouri, USA; Gondwana (GD) - Mount Whelan

263 \#1 and Mount Murray, Queensland, Australia; Baltica (BL) - Andrarum \#3 core,

264 Sweden.

266 Figure 2: Chemostratigraphies of the studied carbonate sections. Isotope data are plotted

267 by stratigraphic height in meters. International series and stages are based on published

268 biostratigraphy and most recent definitions of the subdivisions of the Cambrian (see

269 Supplementary Material). Carbon isotopes profiles from Single Pass and Lawsons Cove 
270 sections and Mt. Whelan \#1 core are from references 8 and 10, respectively. The CAS

271 sulphur isotope profile from Shingle Pass is from reference 15.

272

273 Figure 3: Chemostratigraphic data from the Alum Shale, Andrarum \#3 Core, Sweden.

274 Molybdenum, molybdenum/total organic carbon (Mo/TOC), total iron and aluminum and

275 iron speciation data are plotted along side organic carbon and pyrite sulphur isotope data.

276 Carbon isotope profile is from reference 28. Since Mo covaries with the concentration of

277 organic matter in sediments ${ }^{19}$, Mo concentrations have been normalized to TOC to

278 correct for variations in organic content. Shaded regions of the degree of pyritization

279 (DOP), $\mathrm{Fe}_{\mathrm{py}} / \mathrm{Fe}_{\mathrm{HR}}, \mathrm{Fe}_{\mathrm{HR}} / \mathrm{Fe}_{\mathrm{T}}$ and $\mathrm{Fe} / \mathrm{Al}$ plots display values that indicate anoxia and

280 euxinia: $\mathrm{Fe}_{\mathrm{T}} / \mathrm{Al}$ values above 0.5 and $\mathrm{Fe}_{\mathrm{HR}} / \mathrm{Fe}_{\mathrm{T}}$ above 0.4 indicate deposition under

281 anoxic water columns ${ }^{29}$, and DOP and $\mathrm{Fe}_{\mathrm{py}} / \mathrm{Fe}_{\mathrm{HR}}$ values above 0.75 are conservatively

282 diagnostic of euxinic environments ${ }^{30}$. Note that the decrease and minimum in Mo and

$283 \mathrm{Mo} / \mathrm{TOC}$ correspond to the initiation and peak of the carbon and sulfur isotope

284 excursions, respectively.

286 Figure 4: Examples of the modeled carbon and sulfur isotope composition of the ocean

287 during the SPICE. The sulfur isotope plot shows the effect of varying the magnitude of

288 the transient increase in pyrite burial. In these simulations the burial of rates organic

289 carbon and pyrite sulfur were increased for a half million years to create the isotope

290 excursions. Organic carbon burial was doubled from $4.1 * 10^{18}$ to $8.2 * 10^{18}$ moles/Myrs

291 and pyrite burial was increased from the steady state rate $\left(0.98 * 10^{18} \mathrm{moles} / \mathrm{Myrs}\right)$ by the 
292 factors listed in the legend. Values in parenthesis are the molar carbon to sulfur $(\mathrm{C} / \mathrm{S})$

293 ratios of the transient burial fluxes introduced into the model. The starting marine sulfate 294 concentration in these simulations was $1.5 \mathrm{mM}$. 
Figure 1

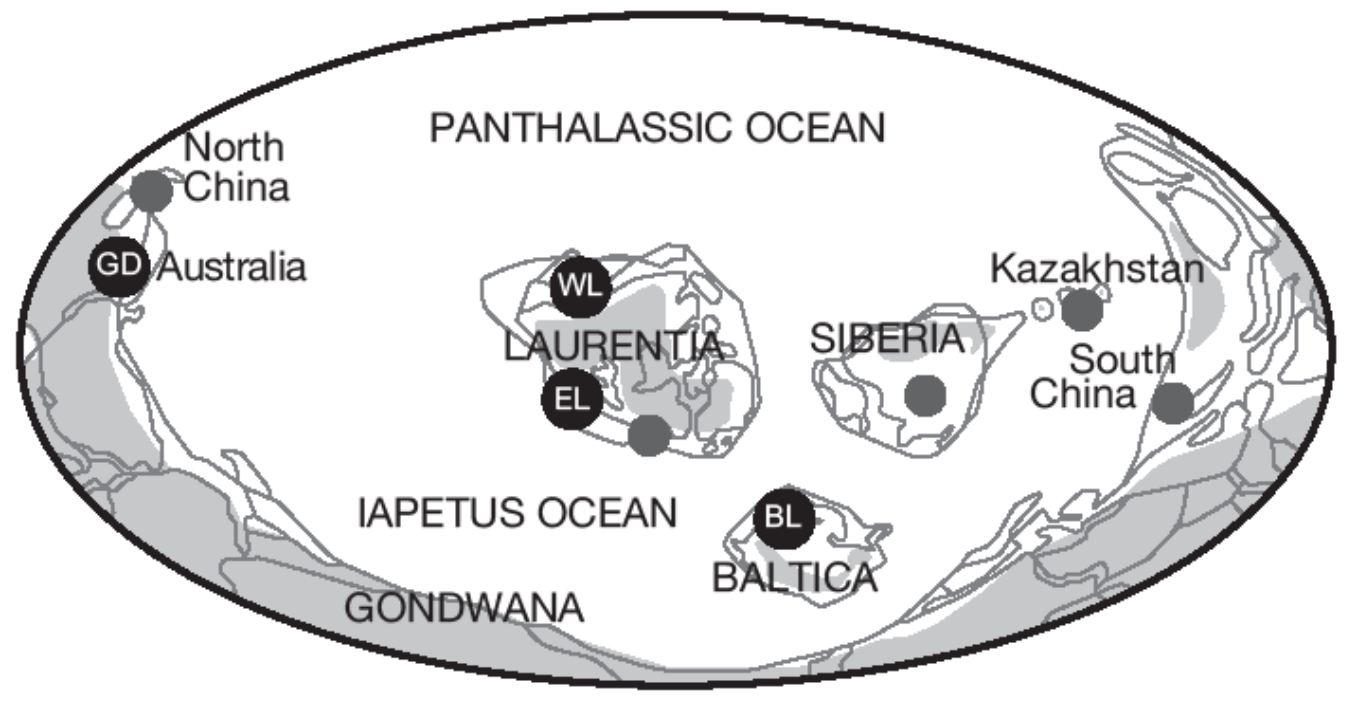


Figure 2

WL
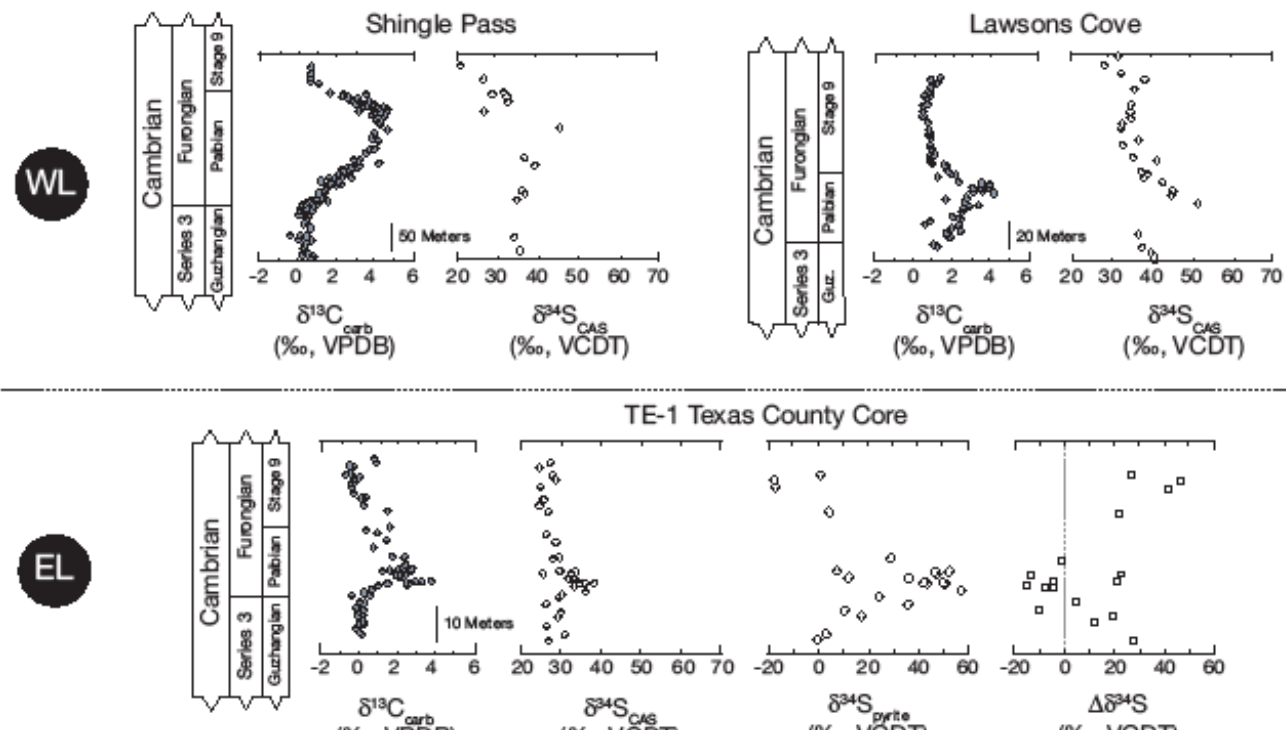
(\%, VPDB)
(\%, VCDT)
(\%, VĆDTT)
(\%, VCDT)

300

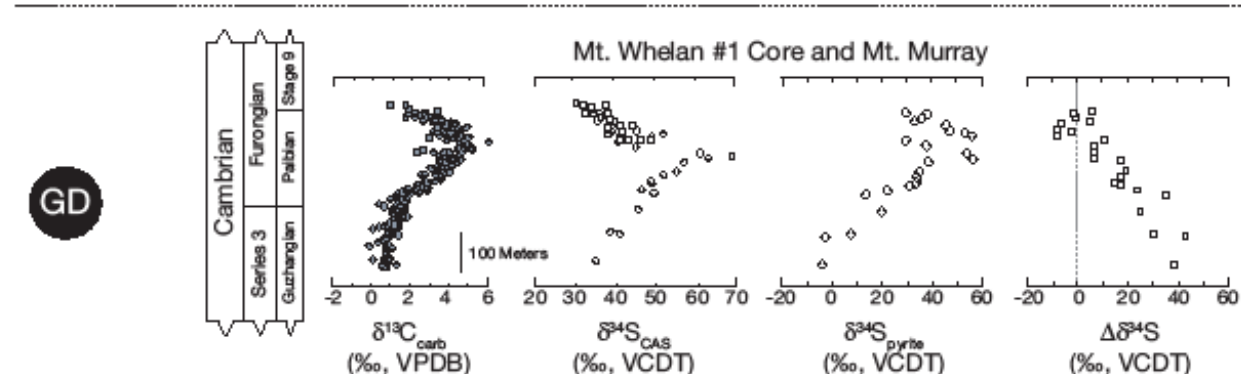

301 
Figure 3

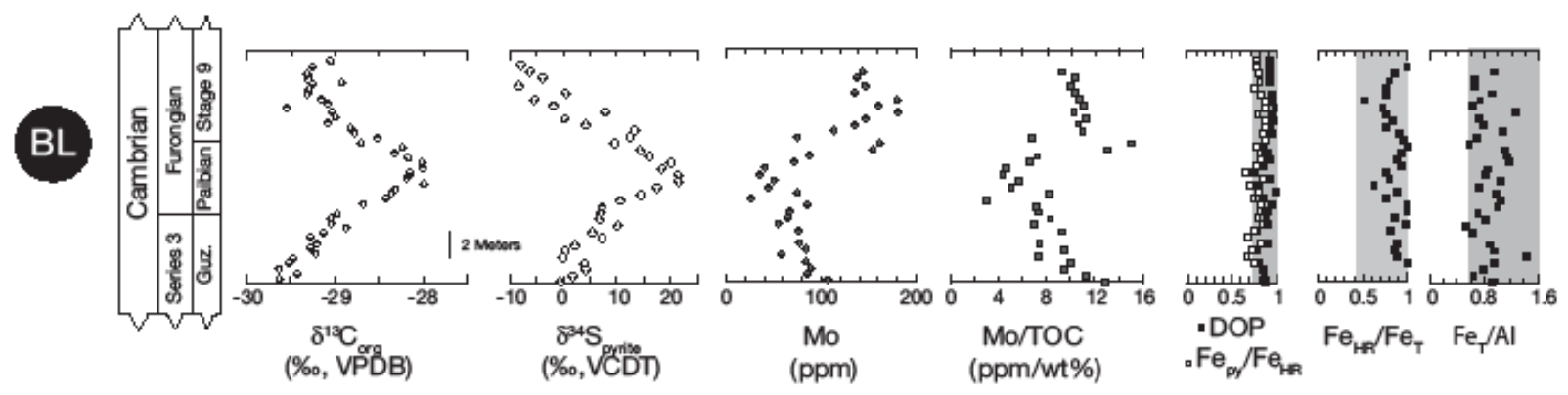


Figure 4
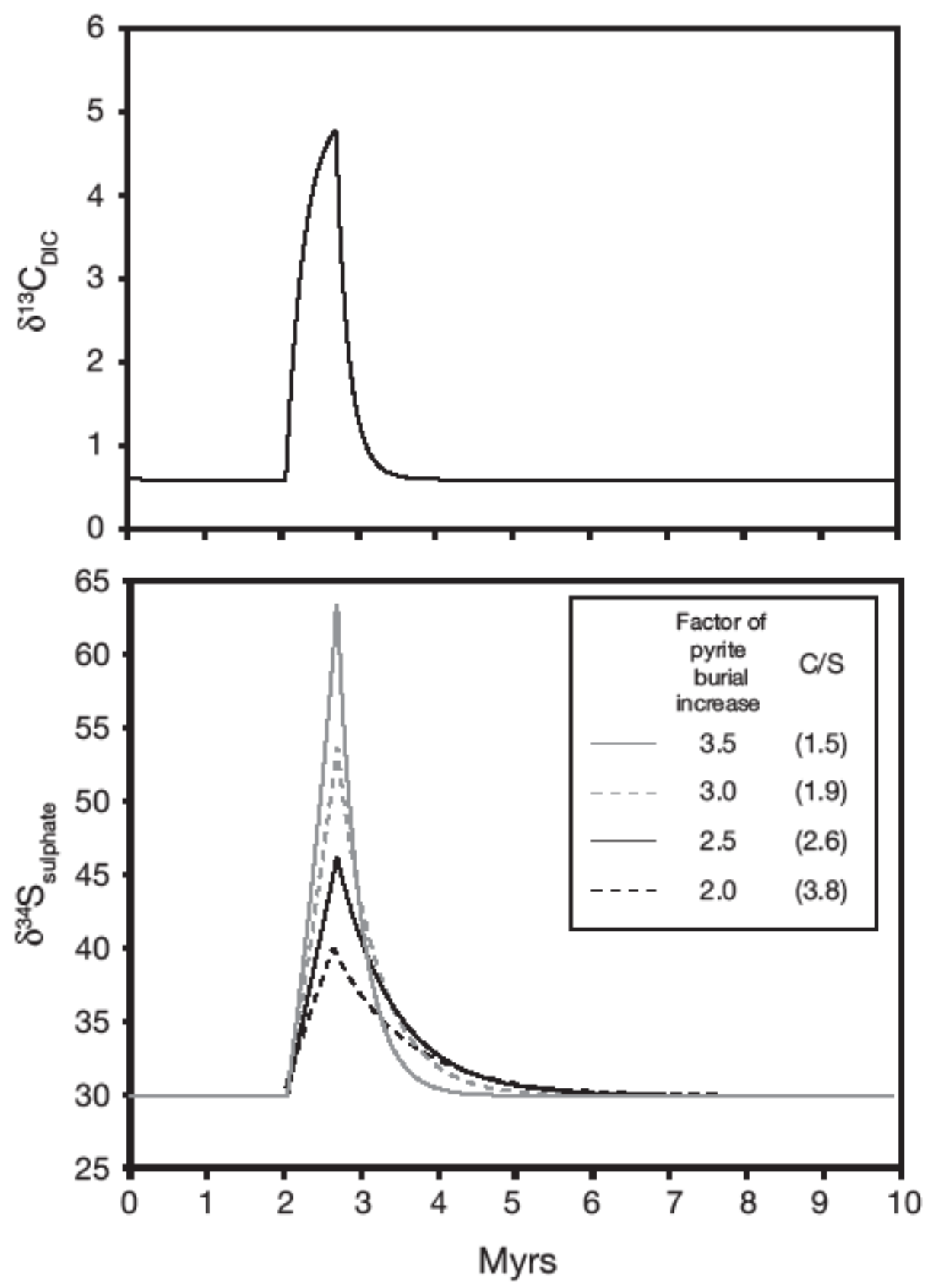